\title{
Saliva Iron Levels to Assess Iron Status in Children
}

\author{
Rostika Flora ${ }^{1 *(D)}$, Mohammad Zulkarnain ${ }^{2}$, NurAlam Fajar ${ }^{1}$, Indah Yuliana ${ }^{3}$, Risnawati Tanjung ${ }^{4}$, Helfi Nolia ${ }^{4}$, Sulaiman Sulaiman ${ }^{5}$, \\ Aguscik Aguscik ${ }^{5}$ \\ ${ }^{1}$ Department of Public Health, Faculty of Public Health, Sriwijaya University, Palembang, Indonesia; ${ }^{2}$ Department of Public \\ Health Science, Faculty of Medicine, Sriwijaya University, Palembang, Indonesia; ${ }^{3}$ Department of Nutrition, Faculty of Public \\ Health, Sriwijaya University, Palembang, Indonesia; ${ }^{4}$ Department of Environmental Health, Polytechnic of Health of the Ministry \\ of Health, Medan, Indonesia; ${ }^{5}$ Department of Nursery, Polytechnic of Health of the Ministry of Health, Palembang, Indonesia
}

Edited by: Sasho Stolesk Citation: Flora R, Zulkarnain M, Fajar NA, Yuliana Tanjung R, Nolia H, Sulaiman S, Aguscik A. Saliva Iron Levels to Assess Iron Status in Children. Open Acces
Maced J Med Sci. 2021 Sep 08; $9(\mathrm{E}): 843-846$ https://doi.org/10.3889/oamjms.2021.677 Keywords: Iron deficiency; Non-invasive diagnostic test; Saliva
*Correspondence: Rostika Flora, Public Health Major, Faculty of Public Health, Sriwijaya University, Palembang Indonesia. E-mail: rostikaflora@gmail.com Received: 03-Jul-202 Revised: 19-Aug-2021 Copyright: ๑ 2021 Rostika Flora Mohammad Zulkarnain Nur Alam Fajar, Indah Yuliana, Risnawati Tanjung Nur Alam Fajar, Indah Yuliana, Risnawati Tanjung,
Helfi Nolia, Sulaiman Sulaiman, Aguscik Aguscik Funding: This study was supported by DIPA of Public Service Agency of Universitas Sriwijay Competing Interest: The authors have declared that no competing interest exists Open Access: This is an open-access article distribute under the terms of the Creative Commons Attribution-
NonCommercial 4.0 International License (CC BY-NC 4.0)

\begin{abstract}
BACKGROUND: Iron plays an essential role in the process of neurotransmitter synthesis and neuron myelination Iron deficiency impacts low cognitive performance, even involved in long-term effects even though iron deficiency has been overcome. Given the impact caused by iron deficiency, it is necessary to monitor the status of iron in the body. Diagnostic tests carried out so far use blood specimens taken with invasive method. This creates fear for the child because of the pain it causes.

AIM: This study aims to obtain a non-invasive alternative diagnostic test in detecting iron deficiency in children using saliva as an examination specimen.

METHODS: The design of this study was case control, with a sample of elementary school children aged 9-12 years and for women who had not experienced menstruation. The sample consisted of 40 people who were taken randomly and grouped into iron deficiency and normal. Determine the group of iron deficiency and normal was based on the results of an examination of serum iron levels. Next, saliva samples were taken to determine saliva iron levels. The characteristics of the sample data were obtained through a questionnaire, while the measurement of serum iron levels was carried out by the spectrophotometric method, and the measurement of saliva iron levels was carried out by the ELISA method. Data were analyzed using Spearman's test
\end{abstract}

RESULTS: Based on serum iron measurements, it was found that the mean serum iron levels in children with iron deficiency were lower than normal children $(38.153 \pm 8.99 \mathrm{q} / \mathrm{dL}$ vs. $79.198 \pm 14.2219 \mathrm{q} / \mathrm{dL})$, on the contrary, on examination of iron levels, it was found that in children with iron deficiency, saliva iron levels were higher than in normal children $(5.745 \pm 3.04 \mathrm{q} / \mathrm{dL}$ vs. $2,576 \pm 1.43 \mathrm{q} / \mathrm{dL})$. The correlation test results showed a significant negative correlation between serum iron levels and moderate iron levels $(p=0.000, r=-0.518)$.

CONCLUSION: Saliva iron levels can be used as an alternative non-invasive diagnostic test to assess children's iron status.

\section{Background}

Iron is an essential microelement for the body and plays an important role in forming red blood cells and the growth and development of children. In addition, iron also plays a role in cognitive function by synthesizing neurotransmitters and myelination of neurons [1]. In adults, less than $5 \%$ of the iron requirement for erythropoiesis is obtained from food, while in children, the iron needed for erythropoiesis is obtained by $30 \%$ from food. If iron needs are not met, then the child will experience iron deficiency. Untreated iron deficiency will progress to iron deficiency anemia (IDA). Iron deficiency and IDA are public health problems in both developed and developing countries. Iron deficiency affects approximately two-thirds of children and adolescents, and it is estimated that around $25 \%$ of preschool children suffer from IDA [2]. In Indonesia, one in four children of primary school age suffers from iron deficiency [3].
Iron deficiency can cause interference or inhibition of growth, both body cells and brain cells. Children with iron deficiency tire more easily, play less, and are more indecisive than healthy children [4]. Iron deficiency that has progressed to IDA can cause impaired mental and motor function, and these effects may be permanent. Several studies have stated that iron deficiency reduces the expression of dopamine receptors, interferes with myelination, or interferes with the function of various enzymes involved in nervous tissue [5], [6], [7].

Given the impact caused by iron deficiency, it is necessary to monitor the status of iron in the body. The iron status in the body can be determined biochemically using various parameters, including blood hemoglobin levels, hematocrit levels, and ferritin in serum. Each parameter can describe changes in the composition of iron in the body. Ferritin is an iron storage protein which is a relatively more accurate estimator of iron stores. Serum ferritin is an indicator of the level of iron stores in the body. Examination of serum ferritin levels is done to determine the diagnosis of iron deficiency 
because serum ferritin levels, as the earliest indicator, decrease when iron stores decrease [8]. However, this examination is an invasive test, which requires blood to detect the iron status. Examination with this method is quite scary for school-aged children because of the pain it causes. This study aims to obtain a non-invasive alternative diagnostic test in detecting iron deficiency in children using saliva as an examination specimen.

\section{Methods}

The design of this study was case control, with a sample of elementary schoolchildren aged 9-12 years and for women who had not experienced menstruation. The sample consisted of 40 children who were taken randomly and grouped into iron deficiency and normal. Determine the group of iron deficiency and normal based on the results of an examination of serum iron levels. Next, both groups were then taken saliva specimens to determine saliva iron levels. Saliva was taken at 9.00-11.00 AM West Indonesian time. During the saliva collection process, the sample was instructed not to eat and drink $1 \mathrm{~h}$ before the saliva collection to minimize food debris and saliva stimulation. The saliva collection was carried out for $5 \mathrm{~min}$ by the spitting method, namely, by allowing the saliva to collect in the oral cavity, and every minute the collected saliva was removed into a funnel and allowed to flow into a sterile saliva pot. The characteristics of the sample data were obtained through a questionnaire. At the same time, the measurement of serum iron levels was carried out by the spectrophotometric method, and the measurement of saliva iron levels was carried out by the ELISA method (Cat. No. E-EL-H0168) using the ELISA kit from Elabscience. Data were analyzed using SPSS 26 using Spearman's test.

\section{Ethical approval}

This research has received ethical approval from the Ethics Commission of the Faculty of Public Health, Sriwijaya University, No.154/UN9.FKM/ TU.KKE/2021.

\section{Results}

Based on the data on the characteristics of children (Table 1), it was found that $55 \%$ of children aged $>10-12$ years and $60 \%$ were female. Data on parental characteristics show that most parents have low education and work as farmers, and $67.5 \%$ of parents have low economic status (Table 1).
Table 1: Frequency distribution of elementary schoolchildren in Tuah Negeri district

\begin{tabular}{lll}
\hline Frequency distribution & $\mathrm{n}$ & $\%$ \\
\hline Age (years) & 18 & 45 \\
$9-10$ & 22 & 55 \\
$>10-12$ & & \\
Gender & 16 & 40 \\
$\quad$ Male & 24 & 60 \\
$\quad$ Female & 25 & 62.5 \\
Mother's education & 15 & 37.5 \\
$\quad$ Low & & \\
$\quad$ High & 24 & 60 \\
Mother's Job & 16 & 40 \\
$\quad$ Farmer & & \\
$\quad$ Unemployed & 26 & 65 \\
Father's education & 14 & 35 \\
$\quad$ Low & & \\
$\quad$ High & 34 & 85 \\
Father's job & 6 & 15 \\
$\quad$ Farmer & & \\
$\quad$ Private employees & 27 & 67.5 \\
Economic status & 13 & 23.5 \\
$\quad$ Low & & \\
$\quad$ High & &
\end{tabular}

The results of the examination of serum iron levels (Table 2) showed that the mean serum iron levels in children with iron deficiency were lower than children with normal serum iron levels $(38.153 \pm 8.99 \mathrm{q} /$ $\mathrm{dL}$ vs. $79.198 \pm 14.2219 \mathrm{q} / \mathrm{dL}$ ). Likewise, the results of the measurement of saliva iron (Table 3 ) showed that children with iron deficiency had lower saliva iron levels than normal children $(5.745 \pm 3.04$ vs. $2.576 \pm 1.43)$.

Table 2: Average serum iron levels in elementary schoolchildren

\begin{tabular}{lllc}
\hline Iron status & $\mathrm{n}$ & $\begin{array}{l}\text { Serum iron level } \\
\text { Mean } \pm \mathrm{SD}(\mu \mathrm{q} / \mathrm{dL})\end{array}$ & $\mathrm{p}$-value \\
\hline Iron deficiency & 20 & $38.153 \pm 8.99$ & 0.000 \\
Normal & 20 & $79.198 \pm 14.22$ & \\
\hline
\end{tabular}

The correlation test results (Table 4) showed a significant negative correlation with a moderate degree of closeness between serum iron levels and saliva iron levels in children.

Table 3: Average saliva iron levels in elementary schoolchildren

\begin{tabular}{lllc}
\hline Iron status & $\mathrm{n}$ & $\begin{array}{l}\text { Saliva iron level } \\
\text { Mean } \pm \mathrm{SD}(\mu \mathrm{q} / \mathrm{dL})\end{array}$ & p-value \\
\hline Iron deficiency & 20 & $5.745 \pm 3.04$ & 0.000 \\
Normal & 20 & $2.576 \pm 1.43$ & \\
\hline
\end{tabular}

\section{Discussion}

This study indicates that the mean serum iron level is lower in children with iron deficiency. Iron deficiency in children can occur due to a lack of iron intake or low iron availability in the diet. The availability of food influences the lack of iron intake in children. The family's economic status determines the availability of food in the household, while the education and occupation of parents play a role in the family's economic status. Characteristic data in this study indicate that most parents have low education

Table 4: Correlation between serum iron levels and saliva iron levels in elementary schoolchildren

\begin{tabular}{lllll}
\hline Iron level & $\mathrm{n}$ & Mean $\pm \mathrm{SD}(\mu \mathrm{q} / \mathrm{dL})$ & $\mathrm{r}$ & $\mathrm{p}$-value \\
\hline Serum iron & 40 & $62.572 \pm 23.778$ & -0.518 & 0.000 \\
Saliva iron & 40 & $4.161 \pm 2.84$ & & \\
\hline
\end{tabular}


and work as farmers, and $67.5 \%$ of parents have low economic status. This condition contributes to low iron intake in children.

Low iron intake in an inadequate diet can cause reduced iron reserve so that the erythropoiesis process will decrease, impacting decreasing hemoglobin levels. Iron is an essential microelement for the body, which is needed to form blood cells, namely, to synthesize hemoglobin [9]. Serum iron levels indicate the availability of body iron because protein binds to iron reserves in the body. Serum iron has a high specificity for diagnosing iron deficiency, especially when combined with other markers such as hemoglobin [10]. Iron deficiency accompanied by a decrease in hemoglobin levels impacts IDA because the imperfect formation of hemoglobin causes red blood cell size smaller (microcytic) and contains less hemoglobin (hypochromic).

The examination of saliva iron levels in this study showed that children with iron deficiency had higher saliva iron levels than normal children. The results of this study are in line with studies conducted by Jagannathan et al. and Mishra et al. who found that saliva iron levels were higher in iron-deficient children than in normal children. However, in the measurement of serum iron, iron levels were lower in iron-deficient children than in normal children [11], [12]. Increased saliva iron levels in iron deficiency are still debated. It is suspected that the increase occurred to maintain enzymatic function in saliva, which depends on the availability of iron. In addition, the ability of saliva to bind iron also has an impact on increasing iron in saliva. When iron in the body drops, the body will maintain high iron in the saliva so that enzymatic functions, which are highly dependent on iron availability, continue to run [13].

The results of the correlation test showed a negative correlation between serum iron levels and saliva iron levels. The results of this study are similar to those of Canatan and Akdeniz's study, which reported a significant relationship between serum and saliva iron levels [14] Likewise, the results of Gawaly and Alghazaly's study stated that there was a negative and significant correlation between serum and saliva iron levels. This shows that saliva iron can be used as a marker of iron deficiency. According to Jagannathan et al., changes in saliva iron occur even before changes

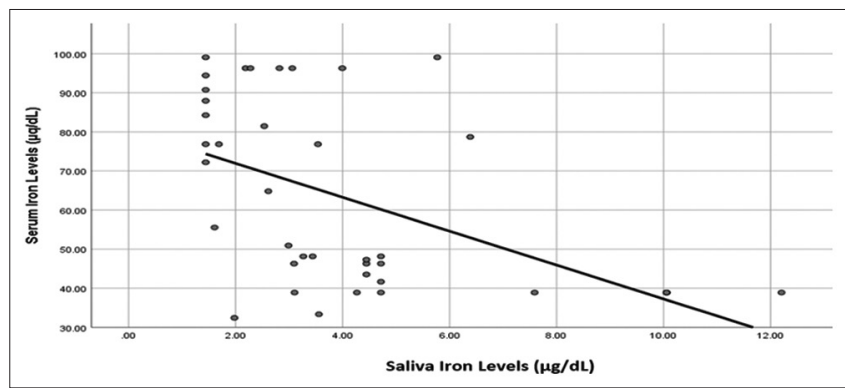

Graph 1: Correlation between serum iron levels and saliva iron levels $(p=0.000, r=-0.518)$ in serum iron [11], [15]. Saliva iron has the same sensitivity level as serum iron [16].

\section{Conclusion}

There is a significant negative correlation between saliva iron levels and serum iron levels. Saliva iron levels can be used as an alternative non-invasive diagnostic test in assessing iron status in children.

\section{Acknowledgment}

This research of this article was funded by DIPA of Public Service Agency of Universitas Sriwijaya. SP DIPA-023.17.2.677515/2021, on November 23, 2020. In accordance with the Rector's Decree Number: 0010/ UN9/SK.LP2M.PT/2021, on April 28, 2021. The authors gratefully acknowledge those who had contributed their generous support in completing this work.

\section{References}

1. Perignon $M$, Fiorentino $M$, Kuong $K$, Burja $K$, Parker $M$, Sisokhom S, et al. Stunting, poor iron status and parasite infection are significant risk factors for lower cognitive performance in Cambodian school-aged children. PLoS One. 2014;9(11):e112605. https://doi.org/10.1371/journal. pone.0112605

PMid:25405764

2. Miniero R, Talarico V, Galati MC, Giancotti L, Saracco P, Raiola G. Iron Deficiency and Iron Deficiency Anemia in Children. London: IntechOpen; 2018. https://doi.org/10.5772/intechopen.79790

3. Kementerian Kesehatan RI. Laporan Riskesdas 2007. Jakarta: Badan Litbang Kesehatan; 2008.

4. Lozoff B, Jimenez E, Hagen J, Mollen E, Wolf AW. Poorer behavioral and developmental outcome more than 10 years after treatment for iron deficiency in infancy. Pediatrics. 2000;105(4):E51. https://doi.org/10.1542/peds.105.4.e51 PMid:10742372

5. Erikson $\mathrm{KM}$, Jones $\mathrm{BC}$, Hess EJ, Zhang Q, Beard JL. Iron deficiency decreases dopamine $D(1)$ and $D(2)$ receptors in rat brain. Pharmacol Biochem Behav. 2001;69(3-4):409-18.

PMid:11509198

6. Ortiz E, Pasquini JM, Thompson K, Felt B, Butkus G, Beard J, et al. Effect of manipulation of iron storage, transport, or availability on myelin composition and brain iron content in three different animal models. J Neurosci Res. 2004;77(5):6819. https://doi.org/10.1002/jnr.20207

PMid:15352214

7. Beard JL. Iron biology in immune function, muscle metabolism and neuronal functioning. J Nutr. 2001;131(2S-2):568S-79. https://doi.org/10.1093/jn/131.2.568s 


\section{PMid: 11160590}

8. World HealthOrganization. Iron Deficiency Anemia: Assessment, Prevention and Control. A Guide for Programme Managers. Geneva: World HealthOrganization; 2001.

9. Bernadette FG, Elaine K. Disorder of Iron and Heme Metabolism. In: Wurm E, editor. Hematology Clinical Principles and Applications. St Louis, Missouri: Elsevier Saunder, Andrew Allen; 2012. p. 254-8.

10. Wu AC, Lesperance $L$, Bernstein $H$. Screening for iron deficiency. Pediatr Rev. 2002;23(5):171-7. PMid:11986493

11. Jagannathan $N$, Thiruvengadam $C$, Ramani $P$, Premkumar $P$, Natesan A, Sherlin H. Salivay ferritin as a predictive marker of iron deficiency anemia in children. J Clin Pediatr Dent. 2012;37(1):2530. https://doi.org/10.17796/jcpd.37.1.ap20543762015370

PMid:23342563
12. Mishra OP, Agarwal KN, Agarwal RM. Saliva iron status in children with iron deficiency and iron overload. J Trop Pediatr. 1992;38(2):64-7. https://doi.org/10.1093/tropej/38.2.64 PMid: 1569637

13. Jenkins GN. Saliva. In: Physiology and Biochemistry of the Mouth. $4^{\text {th }}$ ed. Oxford: Blackwell Scientific Publishers; 1978. p. 284-359.

14. Canatan D, Akdeniz SK. Iron and ferritin levels in saliva of patients with thalassemia and iron deficiency anemia. Mediterr J Hematol Infect Dis. 2012;4(1):e2012051. https://doi. org $/ 10.4084 / \mathrm{mjhid} .2012 .051$ PMid:22973495

15. Gawaly A, Alghazaly G. Serum and saliva ferritin levels in iron deficiency anemia is there is a difference? Hematol Transfus Cell Ther. 2020;42(1):56. https://doi.org/10.1016/j.htct.2020.09.101

16. Kodati S. Correlation of serum and saliva levels in iron deficiency anemia patients. Int J Biol Med Res. 2018;9(2):6317-20. 